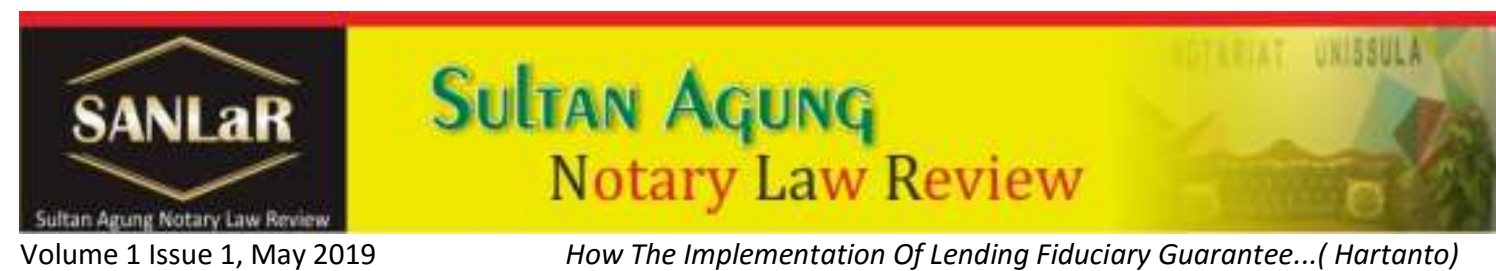

\title{
How The Implementation Of Lending Fiduciary Guarantee?
}

\section{Hartanto $^{1}$, Fatmasari Wulandari ${ }^{2}$ and Ratih Mega Puspasari ${ }^{3}$}

Abstract. Lending by banks basically have an assurance bank of capability and debtors to repay their debts, and must be conducted on the basis of the principle of sound lending and the precautionary principle so that the credit does not harm the interests of the bank, customers debtor and the public depositors. It must be implemented, given the bank's loans to risk that is not returned in accordance with the agreement. One of the factors that would cause the value of bad loans is not comparable to a loan guarantee. In the banking world generally embraced the concept of an assessment of the highest collateral $80 \%$ of the value of the collateral, and the loan amount can be given is $80 \%$ of the value of the collateral.

Keywords: Fiduciary; Credit; Implementation.

\section{Introduction}

Fiduciary Guarantee is defined as right over collateral on moving objects both tangible and intangible, particularly on building that cannot be encumbered by mortgage and remain in a possession of fiduciary provider as a collateral for the payment of certain debt which provides the preferred position towards fiduciary recipient to other creditors ("Fiduciary Guarantee").

In order for the concerned parties to be covered with legal certainty, Article 11 Paragraph (1) of Law No. 42 of 1999 on Fiduciary (“Law No. 42/1999“) suggests that any objects loaded with Fiduciary Guarantee shall be registered.

The procedure of Fiduciary Guarantee Registration along with its other requirements is regulated under Government Regulation No. 21 of 2015 on the Procedure of Fiduciary Guarantee Registration and the Cost of the Deed of Fiduciary Guarantee ("GR 21/2015") which has been enacted since 6 April 2015. This regulation revokes the previous Government Regulation No. 86 of 2000 on the Procedure of Fiduciary Guarantee Registration and the Cost of the Deed of Fiduciary Guarantee ("GR 86/2000")

\section{a. The Application Procedure}

Based on article 4 of GR 21/2015, the registration of Fiduciary Guarantee shall be submitted no longer than 30 (thirty) days since the commencement date of the establishment of Fiduciary Guarantee Deed ("Deed").

\footnotetext{
${ }^{1}$ Director of Inland Waterways, Lake, and Ferries Polytechnic of Palembang (Poltektrans SDP Palembang), Email: hartantosatya@gmail.com

2 Students Doctor of Law, Sultan Agung Islamic University (Unissula), e-mail: wulanz_8282@yahoo.com

3 Students Doctor of Law, Sultan Agung Islamic University (Unissula), Email: ratihmegapuspa@gmail.com
} 
Furthermore, to conduct the registration of Fiduciary Guarantee, the recipient of the Fiduciary, and/or representative, and/or applicant ("Applicant") shall submit such registration to the Minister of Law and Human Rights ("MLHR"). Previously, GR $86 / 2000$ stipulated that the application of Fiduciary Guarantee ("Application") was submitted in a written form to MLHR in Indonesian language through the fiduciary Registration Office by attaching the Registration statement of the Fiducary Guarantee. However, such registration method is believed to face an obstacle by considering the huge amount of applications obtained beyond the capabilities of human resources and existing facilities. In solving such issue, the registration using a written application has been amended with Fiduciary Guarantee registration through an electronic system in accordance with Article 2 Paragraph (2) GR 21/2015.

b. The application of the registration of Fiduciary Guarantee consists: The identity of the fiduciary provider and fiduciary recipient; Date, number of Fiduciary Deed, name, and the domicile of the notary who made Fiduciary Deed; Principal agreement data guaranteed by fiduciary; A description regarding item that becomes an object for Fiduciary Guarantee; The value of the guarantee; and Value of an item that becomes an object for Fiduciary Guarantee.

Moreover, after the registration complies with conditions stated above, the Applicant will obtain the proof of registration as follows: Registration number; Date of filling the application; Name of the Applicant; Name of Fiduciary Registration Office; Type of application; and Fiduciary Registration fee.

The electronic record of the registration shall be performed should the payment of the registration fee has been made by the Applicant. Such payment can be done through the receiving bank.

The Fiduciary Guarantee will be created electronically on the date of the record of Fiduciary Guarantee. Fiduciary Certificate ("Certificate") shall also be signed electronically by the official at the fiduciary registration office. Then, the molding of the Certificate will be performed pursuant to the date when the registration of Fiduciary Guarantee was recorded.

The Cost of the Deed:

- The cost of the Deed shall be determined based on the value of the guarantee with the following provisions;

- The amount of guarantee is up to 100,000,000.00,- (one hundred million Rupiah), the cost of the Deed is $2.5 \%$ (two point five percent) maximum;

- The amount of guarantee is over 100,000,000.00,- (one hundred million Rupiah) up to $1,000,000,000.00$,- (one billion Rupiah), the cost of the Deed is $1.5 \%$ (one point five percent) maximum; and;

- The amount of guarantee is above 1,000,000,000.00,- (one billion Rupiah), the cost of the Deed is based on the agreement between the Notary and the parties, however $1 \%$ (one percent) is the maximum of the value of the object of the Deed. 


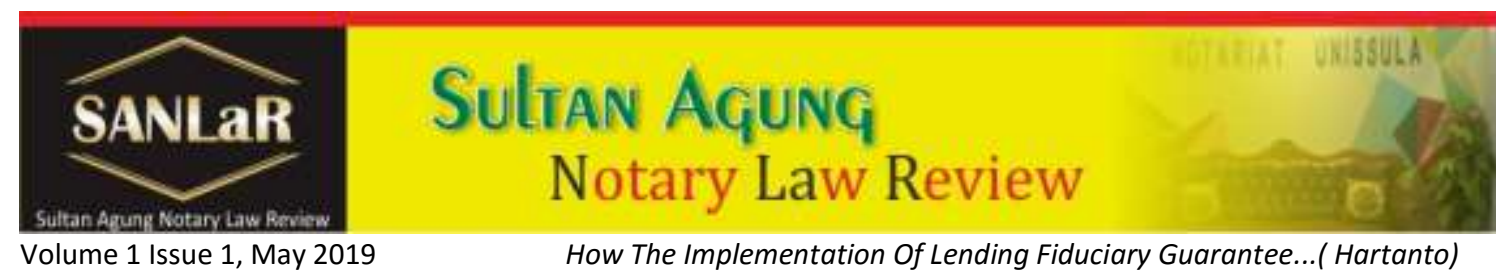

Fiduciary insurance is one of the guarantees of matter known in the positive law ${ }^{4}$, In Circular Letter No. 4/426 / BFL / PK dated March 16, 1972 stated that the binding guarantee for movables used mortgages and insurance agency or credietverband. This article is then changed by Circular Letter No. 23/6 / UKU dated February 28, 1991 which stipulates that the binding of collateral be conducted in accordance with the legislation in force. In fact, fiduciary in the lending business became one of the efforts that the loan granted to the debtor can be restored smoothly, face many obstacles in its implementation.

As we know that the funds or money is one of the factors essential capital to run and grow a business economics or business. To obtain funds for the implementation and development of business enterprises can be reached by carrying out lending / credit through banking services, with sufficient guarantees either movable or immovable objects. Bank is an entity that collects funds from the public in the form of savings and channel them to the public in the form of loans or other forms in order to improve the standard of living of the people (Article 1 of Law No. 10 of 1998 on Banking). Thus the bank is a business entity engaged in the services sector.

Banking has a major role in boosting the national economy. This is consistent with the bank's main function is as an institution collector and distributor of public funds. Functions performed community fundraiser in the form of acceptance of deposits, while the function of providing funds, among others in the form of loans with collateral. Products are sold banking business is not without risk. Business risks that will occur among banks, especially regarding credit. Agreement to extend credit, in general, a standard agreement between the bank and the debtor. To the debtor only given choices take it or leave it. If you agree with the clauses the agreement offered by the bank, then pass the credit agreement, but if not then the credit will not be granted by the bank. In this position the banks are in a stronger place. When viewed from the side of the business such positions may occur, but when viewed from the purpose of lending to support economic development, then the unbalanced position so would be disastrous. The condition has been perceived by many banks with problem loans.

Lending by banks basically have an assurance bank of capability and debtors to repay their debts, and must be conducted on the basis of the principle of sound lending and the precautionary principle so that the credit does not harm the interests of the bank, customers debtor and the public depositors. It must be implemented, given the bank's loans to risk that is not returned in accordance with the agreement, so the bank before the credit granted, the bank should conduct a careful assessment of the character, ability of capital and reserves (collateral) as well as the debtor's business prospects. ehubungan with it, even though the collateral (guarantee) is not an absolute thing in lending, but in general practice elements of the collateral (collateral) is a factor

${ }^{4}$ Kartini Mulyadi and Gunawan Widjaja, Privileges, and Mortgages Pawn Prenada Media, Jakarta: 2005, p. 203. 
commonly considered by banks, among others, by dipersyaratkannya collateral (collateral) which can be used as repayment debt in the event the debtor does not fulfill its obligations to the bank.

One of the factors that would cause the value of bad loans is not comparable to a loan guarantee. In the banking world generally embraced the concept of an assessment of the highest collateral $80 \%$ of the value of the collateral, and the loan amount can be given is $80 \%$ of the value of the collateral. Determination of the value of collateral for the objects that will be the object of encumbrance no clear reference, and not taking into account the value of the rights owned by a holder of the right, so that sanctions against violations of the determination of the value of the guarantee can not be given.

Banking guarantees in the business world is one effort that loans granted to borrowers paid back in accordance with the agreed time period to get the results in the form of profits from the business. The fact that the case of late by the mass media and literatureliterature of existing literature, is constrained in take collateral to pay off the debt in accordance with the agreement with the debtor's debts as well as the constraints faced in the implementation of the collateral.

With the affirmation of construction in Act Number 42 of 1999 regarding Fiduciary that objects become fiduciary remain in control of the debtor or guarantor is fiduciary, so that the debtor is not too late for his efforts and use objects assurance, can create a business climate and a healthy trade and dynamic so economic actors and entrepreneurs can develop and progress without neglecting its obligations. By setting up a comprehensive fiduciary in Fiduciary Law is: have a preferred position for creditors fiduciary recipient; debt guarantee either existing or still be there; fiduciary must be registered; executorial magnitude fiduciary certificates; jamainan loading loading fiduciary can not be done again; dalamtangan object fiduciary follow anyone.

\section{Research Methods}

The method used in this research is the implementation of juridical sociological. Juridical carried out to analyze the implementation of the agreement (business) over the Internet from the aspect of legislation or of the normative aspect. While the sociological approach is intended to analyze the factors of progress in implementing the agreement as happens in practice. In line with the intent and purpose of the study to be achieved, then the type of research is descriptive, which gives an overview (description) carefully as possible about the object of research with a representative selection of materials.

\section{Result and Discussion}

Setting security institutions must comply with the traffic needs of society in modern law, and with regard to the development and effects of the security institutions abroad that are very useful and necessary for the development and promotion concept hukum.54 mortgage as security agency has several advantages that greatly needed economic actors, deserves to be maintained in the Indonesian Legal system needed revamping although accurate at the time of construction of the Indonesian Civil Code. Before the Law Number 42 Year 1999 regarding Fiduciary, little guidance that can be held as a 


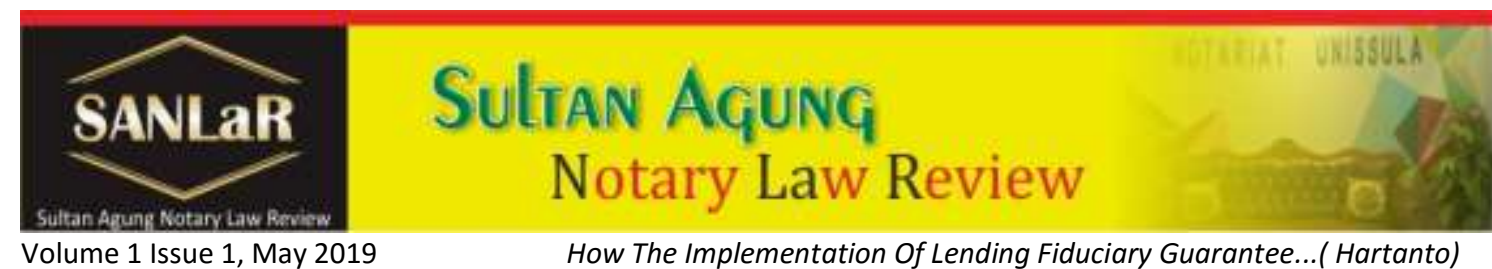

reference for the enforceability of fiduciary instruments. There are also some statutory provisions pertaining to fiduciary as an instrument of collateral, despite that in general there is no technical guidance regarding the implementation of the fiduciary instrument. Birth of fiduciary purely based on the provisions of Article $1320 \mathrm{KUH}$ jo Pedata 1338 on freedom of contract ${ }^{5}$,

The presence of Fiduciary Law in general is very necessary. Act defines the fiduciary agreement as collateral rights on moving objects, both tangible and intangible, and immovable in particular building can not be encumbered encumbrance. It is referred to in Law No. 4 of 1996 on Mortgage which remain in control of fiduciary giver as collateral for the repayment of certain debt position yagn give precedence to the recipient of fiduciary against other creditors. With this law the imposition of a security interest in moving objects in a non-possory be more legal certainty. Because, statuas creditor secured by the registration authorities to register the imposition of fiduciary yangberfungsi to prevent the imposition of fiduciary on the same goods without the knowledge of fiduciary first recipient ${ }^{6}$,

Application security law regime still awaiting the results of the implementation of the Act. 42 of 1999 on Fiduciary, this time in view of the fiduciary instrument, people are still sticking to the old legal framework that not many lessons to be learned from implementation. In Indonesia, banks still hold a dominant portion of the financing scheme as a whole. This is because there is no legal certainty on fiduciary. The creditor must take collateral fixed objects, such as mortgage / encumbrance, or take the form of a guarantee that is the belief common claims against the assets of the debtor as a personal guarantee, or guarantee company ${ }^{7}$, Both types of guarantees have disadvantages.

Mortgages and guarantees the rights tanggunganmerupakan expensive, while personal and corporate guarantee is a guarantee risky. Banks and businesses think that only the perbankanlah are able to finance and have the capability to adjust the risks arising from such guarantees, that is execution, high costs and so forth. This view is a view that is inherited since tens of years. Indonesian Banking umumnyahanya see the eyes of the non-possessory collateral material such as fiduciary and would only accept a fiduciary as complementary collateral only where there is no guarantee immovable pledged as primary collateral. Some Bank Governments are taking a more unique scheme, because

\footnotetext{
${ }^{5}$ Sri Soedewi masjchun sofwan, SH. Law On Mortgage arrangement, Kreditverban and Fiduciary, In the book Security Law Seminar, Hosted by: National Legal Development Agency, the Department of Justice in collaboration with the Faculty of Law, University of Gajah Mada in Yogyakarta, publisher: Binacipta, Bandung, p. 38.

${ }^{6}$ http: /www.hamline.edu/apakabar/basisdata/1997/02/0001.html.

${ }^{7}$ Prof. R. Subekti, SH., Guarantees To Lending According to Indonesian law, Publisher: PT. Citra Aditya Bakti, Bandung, 1989, p. 66.
} 
its mission extend credit to small business, then the insurance scheme becomes unreal and often ignored aspects of the guarantee.

Based on the analysis of data from field research, can put forward some important things pertaining to the subject matter in this study, namely: Things that should be stipulated in the deed of credit agreement (PK) with respect to the binding of the fiduciary, in general, respondents say that: whole goods bound by fiduciary must be included / mentioned explicitly, such as the type, quantity, value, number and date of ownership (invoice / receipt, sale and purchase agreement), the storage location of the goods, number and date of the deed binding. Besides, proof of ownership of the goods to be delivered and controlled by the bank, it is to avoid the item pledged back to the other bank. The commonly stated in the deed of credit agreement is in addition to the problem collateral, among other things: The credit facility; the credit amount; Purpose of Use of Credit and Term Loan; Lending, Loan Provisions; Costs; Credit payments; an end to the Treaty; Warranties and insurance, among others contains a provision that will be made and signed a guarantee agreement (fiduciary) individually which is an integral part and a unity with the Credit Agreement; Guarantees will be insured on condition Banker's Clause; Negligence / defaulting borrowers; domicile Etc

Regarding the rights and obligations of each of the parties (Debtor and Creditor) in the credit agreement with fiduciary guarantee, in the opinion of the majority of respondents, are as follows:

- Debtor Rights: Receiving / draw the appropriate credit facility approved ceiling Borrower and the Bank; Use / enjoy objects fiduciary; Acquire the remaining sales if done sales / auction.

The debtor obligations, among others: To pay the costs (Provisions, Adm and other costs); Paying Credit Interest; Pay installments kredit; Providing Security / Collateral; Doing binding credit guarantees with Rducia (in Notaril); Opening an account / savings in the bank; Maintaining the security object, replacing the damaged part security object; Periodically submit reports on the value of collateral object; Insuring the security object; Not doing binding guarantees with other banks on the same object.

- Creditor Rights:

Receive costs (Provisions, Adm and other costs); Accepting Credit Interest; Accepting credit installments; Receiving Security / Collateral; Sell a security object on title eksekutorial or through public auction or through a sale under arms by agreement with the debtor; Checking the state of the object and fiduciary.

Liabilities Creditors, among other things: Provide / unfreeze credit facility in accordance ceiling approved the Borrower and the Bank; Returns the object fiduciary if no longer a guarantee anymore / keel and issuing Roya.

Based on the opinion of the majority of respondents, that's legitimate and legal effect on a credit agreement with the fiduciary, things that have to be met / performed, 


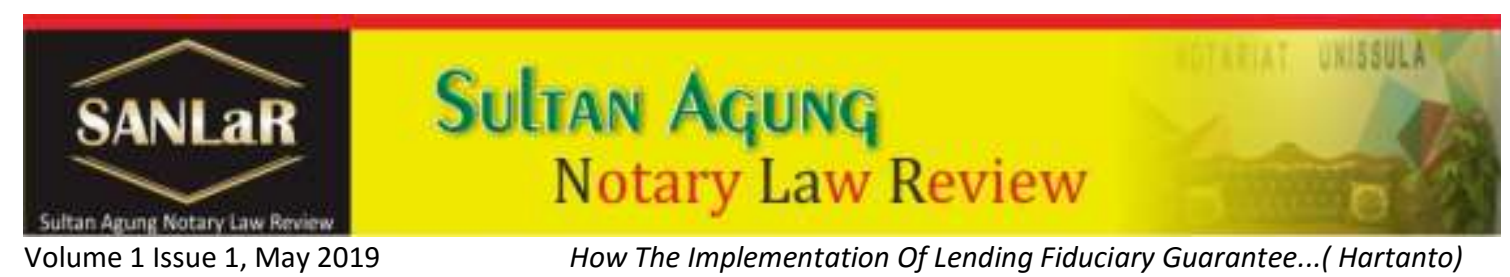

among others: Credit agreements should qualify the validity of the agreement in accordance with Article 1320 of the Civil Code, namely: Agree to the parties entering into the agreement; Ability to make a deal; A particular case the agreement; and a lawful cause; Credit agreement signed by the competent authority; Do binding credit guarantees (Fiducia is Notaril); Deed fiduciary (AJF) is an additional agreement / followup / accesoir of PK, so it should be in the AJF load: Identity fiduciary giver and the recipient; number and date of PK and all amendments thereto that the basic lending; The description of the goods which become the object of fiduciary. Inclusion of these data shall be in accordance with the data contained in the annex PK. It was intended to avoid any disputes / legal problems for banks and customers in the future.

Regarding the mechanism / procedure execution of the goods as collateral fiduciary, if the debtor is unable to return his credit on time, in general, respondents say that: If the debtor / donor fiduciary breach, the bank must notify in writing to them to immediately hand over the object fiduciary and the debtor shall submit it to the bank. Once the goods are controlled by the bank, then the bank's actions subsequent to execute a fiduciary. The mechanism / procedure execution of the goods as collateral fiduciary can be done by:

- Implementation executorial title of fiduciary assurance certificate (SJF) by the Recipient fiduciary. (In the Fiduciary Certificates generated Notaril, are the words of Justice Demi Based on God "who has the power eksekutorial same court decision that has obtained permanent legal force);

- Sales objects that become the object of fiduciary on power Receiver Fiducia (Bank) through a public auction and take repayment of its receivables from the sale.

- Sales under the hand which is based on an agreement Giver (the Borrower) and Receiver Fiduciary (Bank) if in this way can be obtained the highest price that benefits the party.

The implementation of the new sales or auctions can be done after the expiration of 1 (one) month since notified in writing by the owner of the goods and or bank to the parties concerned and published in at least two newspapers concerned area. Proceeds from sale / auction is used to satisfy the obligations of the debtor in connection with the provision of credit, and the excess will be returned to the owner of the goods / guarantee.

The execution problems for the banks is very important, because in accordance with the functions of security interest relating to the provision of credit is as the last bumper ?? ?? that loans granted by the bank can be returned and profitable, by way of execution / sell credit collateral and the result earmarked for debt repayment of the debtor, whereas if the proceeds of such sale of a remaining balance after the use of repayment, then the rest of it is returned to the debtor. Furthermore, if from the sale proceeds are Kekeurangan, then the shortfall must be paid by the debtor, but using konkurent yagn 
rights pursuant to Article 1131 of the Civil Code are relatively weak. In fact, the rights attached to the loan collateral is not entirely easy to implement.

Easiness it actually has strived for example in UUHT and in UUJF use within the content can be expressed as follows: Article 14 paragraph 2 of Law Mortgage and Article 15 paragraph 2 of Law Fiduciary, which said in Sertifikanya berirah-irah ?? SAKE OF JUSTICE UNDER THE ONE ALMIGHTY ONE??; UUHT Article 14 paragraph 3 and Article 15 paragraph 2 UUJF mentioned that the Encumbrance Certificate has the same executorial power with a court ruling has obtained permanent legal force; Article 20 and Article 29 UUJF UUHT the effect that if the debtor in default, then the object guarantees can be made; by way of implementation executorial title (as a criminal offense anyway); sell themselves through a public tender; upon agreement of both parties can sell under the counter.

Although obviously the laws governing it easy for lenders to sell credit collateral object is either done through an auction or sales office under the hand, but in practice there are still obstacles atersebut is still needed Fiat Execution of Court. Based on the explanation of Article 14 paragraph 2 and 3 of the Law Encumbrance as graded above, that there are words ?? through ordinances and using executif parate institutions in accordance with the Civil Procedure Code ?? regulations. This means that even if the debtor has to do eye injury. In practice the auction office would ask the court fiat about the execution of the credit guarantee. Without the establishment of the credit guarantee pengadilanmengenai execution, sales execution will have difficulties and there are still legal issues ?? ??. Very often, even though the court has determined their object the execution of loan collateral, the debtor held rebuttal efforts regarding the determination of the execution of the reasons are acceptable judges. It likewise will extend the execution of credit guarantees.

In accordance with the explanation of Article 8 of the Banking Act which has been described above consists of the guarantee credit guarantee principal and additional warranty. Principal guarantee is the object financed with the credit. In practice this basic guarantee, especially in the working capital loans are goods inventory in the form of bills, supplies, raw materials, and so on. Even has held a variety of efforts, such as by checking the physical way (on the spot) and research reports (on desk), but due to fluctuations in the inventory of goods is relatively fast and difficult to monitor, then bank it difficult to determine the amount of certainty. By the time the debtor breach of these issues will arise, because the amount of merchandise that had already become very small, as well as existing bill compared to loans, even if coupled with additional collateral. In demikan position of banks will experience a dilemma choice, if the collateral is sold, it can not cover the entire debt to the bank. If the business of the creditor is still considered feasible, then the bank would usually use mortgage debt rescheduling or reduction in lending rates. It is simply taken to mitigate greater losses. With the existence of this UUJF such problems particularly relating to guarantees in the form of goods which become the object of Fiduciary has been gaining attention, so as to reduce the risk of banks. 


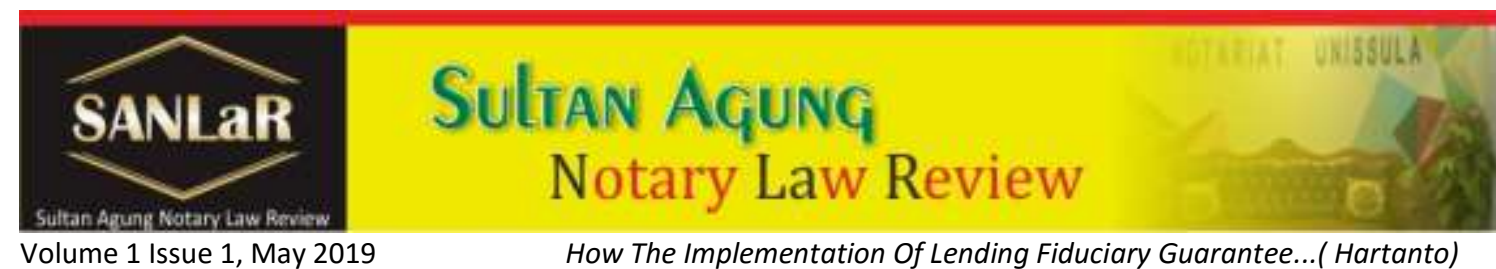

Things that must be done to be able to execute the deletion / deletion fldusia guarantee, if the debtor has to repay loans in accordance with the agreement, based on data analysis of the results of field research shows that, in general, respondents mengetakan, that:

- Fiduciary recipients (Bank) notify the Fiduciary Registration Office regarding the abolishment of fiduciary assurance by attaching a statement that the credit / loan giver Fiduciary (debtor) has paid off.

- Based on the information from the Bank as mentioned in point a, Fiduciary Registration Office (KPF) crossed Fiduciary registration of the Register of Fiduciary.

- Fiduciary Registration Office (KPF) issue a certificate stating Fiduciary Certificate is no longer valid.

If the credit facility has been repaid or goods in question does not fare well fiduciary (since replaced), the bank must return the proof of ownership of the goods / objects fiduciary to dibitur / giver fiduciary / owner bail and is accompanied by a letter addressed to the KPF Roya.

Based on the results of field research data analysis, it can be argued that the constraints that are often encountered in the context of execution of the fiduciary goods, in general, respondents said:

- Fiduciary institution represents the transfer of ownership of an object on the basis of trust, so that objects that the transferred ownership rights remain in the control of the owner of the object. Thus as a result of physical mastery of objects that are in the Giver Fiduciary, then it will be executed when the object is sometimes Fiducia Security has been damaged or lost or berpindahtangan and it is this which became one of the obstacles;

- In addition Fiducia Security as a form of guarantee institutions as stipulated in Law No. 421999 not accommodate a complete and comprehensive manner on the implementation by the recipient Fiduciary eksekutorial rights field;

- The value of fiduciary does not fit anymore because it is damaged, not maintained properly debtor, thus causing losses to the bank;

- Special objects collateral in the form of stock / inventory, equipment (inventory), furniture, machines have been transferred by the debtor without the knowledge of the bank;

- Sita eksekutorial that directly can be done in the execution of fiduciary, in practice by KP2LN officer must be sought from a court warrant.

In addition, the Fiduciary places as stipulated in article: 1, paragraph 2 and 4, Article 7, Article 9, Article 10 UUJF, very spacious namely: Benda bergerah both tangible and intangible; Immovable particular building can not be encumbered encumbrance referred to in UUHT; Debt that already exist and which will arise in the future which has been agreed in a certain amount and debt at the time of execution can be quantified by the principal agreement creates obligations Yanga meet an accomplishment; Results of 
Objects is the object of Fiduciary; Insurance claims, for the object that is the object of fiduciary insured.

However, pursuant to Article 3 UUJF objects mentioned above do not apply to: Mortgage relating to land and buildings, all the legislation in force determining the collateral for these objects shall be registered; Mortgage on the ship listed to the gross tonnage is 20 (twenty) M3 or greater; Mortgage on the aircraft, and; Pawn.

The extent of the object of Fiduciary This should represent an opportunity for banking institutions to create services products credit in accordance with the objects owned by the debtor with the institution of fiduciary this, but the implementation in practice of bank loans, as provisions for the implementation of UUJF not yet there, then these opportunities have not been utilized optimally.

Assignment Receivables (Cessie) as stipulated in Article 19 paragraph 1 is actually coiling cessie institutions. Which menadi problem is the obligation to register these cessie by a new lender, the Fiduciary Registration Office. Is a separate registration with the registration dilakaukan Fiduciary, or separately.

Benda diversion Stock: Droit de suit, namely the right to follow the above objects into an object does not apply to fiduciary inventory objects. However, Article 21 (2) does not apply if there has been a breach of contract by the debtor and a third party or fiduciary giver. This would be detrimental to a good buyer, on objects using fiduciary collateral inventory. Although already protected under article $22 \mathrm{UUJF}$, the problem is if the purchase is made on credit, and cash loan installments by the seller does not diseetorkan. Thus a buyer of goods, such as cars would be difficult to obtain reg.

Imposition process: an important stage in the binding of collateral is loading stage and the stage of registration. Loading phase provided for in Article 4, 5, and 6 UUJF. As a follow-up agreement (acesoir), Fiduciary arise due to the principal agreement. Fiduciary must be made in notariiil, with the contents of at least: The identity of the giver and the recipient of fiduciary; Data Agreement yagn guaranteed principal fiduciary; A description of the object is the object of fiduciary; Value of the agreement; and value objects that become the object of fiduciary. From these conditions, in practice it turns out obligations fiduciary deed that must be notarized made, especially in the case of retail credit, there are objections to its cost.

Phase Registration: By paasl 11 (1) object encumbered with a fiduciary must be registered. Etymologically as listed is the object, then the system does not use the pendaftarana fiduciary registration system theory in general, ie the system Registration of Deeds (listed is legal manufacture / aktanya) or the Registration of title (which didafrar is right). But if we look at Article 13 (2) UUJF registration system adopted is actually a system of registration of title, together with a system of security rights in UUHT pendaftarana.

Problems Associated With Fiduciary Registration Office. In accordance with article 14, item 3 UUJF, fiduciary born on the same date as the date he noted in the book fiduciary fiduciary list. Registration is done on Fiduciary Registration Office. But until now the 


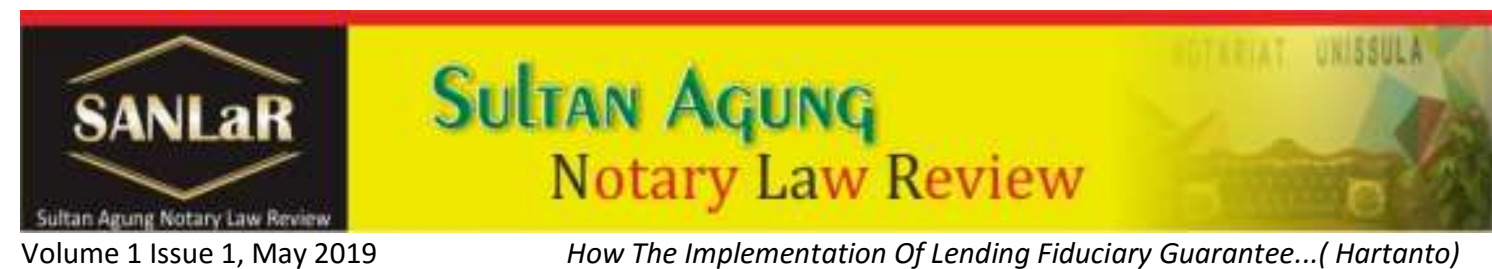

registration office can not be executed in full. In this case for the implementation of the UUJF rules should also be published soon observance.

Problems Associated With Fiduciary Repeat. According to Article 17 states that the Giver Fiduciary UUJF prohibited from re-exposure of the fiduciary becomes the object of fiduciary already registered. Furthermore, based on the explanation trades 17 was declared the ban as a reason for the ownership of these objects have been transferred to the recipient of fiduciary. While based on Article 28 states that ?? if on the same object into fiduciary lebihdari 1 (one) fiduciary agreement, the right of precedence referred to in Article 27, awarded to those who first register it to the Fiduciary Registration Office. The logic is that if there is a ban on holding the fiduciary agreement, means no more than one fiduciary.

Problems Associated With The Fiduciary places abroad. According to Article 11, paragraph 2 UUJF contents are loaded fiduciary object is outside the territory of Indonesia, still must be registered. This article does not regulate where the place of incorporation in Jakarta or elsewhere. Besides, how its execution.

Transitional Provisions. Although defined in Article 37 paragraph 1 that the imposition of Objects is the object of Fiduciary previously remain valid, but these terms are common, which is limited by the provisions of Article 37 (2), namely within 60 days since the establishment of the Office of the Register of Fiduciary, all Fiduciary agreement must comply with the provisions of UUJF, except the provisions concerning liability Fiduciary deed governed by article 5 (1) the fiduciary obligation manufacture warranty deed be notarized. So for Fiduciary who are still there, just held the agreement changes and adjustments as set out in Article $6 \mathrm{UUJF}$, but shall be registered in the Register of Fiduciary (after). Article 38 UUJF contents of all laws and regulations regarding fiduciary remain valid until revoked, replaced or refurbished. In this UUJF not found repeal provisions apply expressly to indicate provisions repealed, as the Act in general (at least, the existing jurisprudence so far).

With their fiduciary insurance agency, which allows objects warranties remain in power in the debtor / sipemilik goods constitutum possessorium, allowing that other creditors may be harmed. Although this is only possible in the case of a guarantee fiduciary evil bertikat possible ${ }^{8}$ :

\section{- Fiduciary reset}

Constitutum handover pessessorium by fiduciary giver that evil-meaning, can be abused by the fiduciary. That is surrender again fiduciary ownership rights as collateral to a third party, which in this case would be the second fiduciary holder. The question is whether the second sikreditor can obtain ownership rights to the

\footnotetext{
${ }^{8}$ A. Hamzah, Institute of fiduciary and implementation in Indonesia, Jakarta, Indhill-CO1, 987 hlm.61
} 
object or whether creditors of the first with the road thus becomes lost his property. This is the second delivery of the property as collateral to the creditor, does not eliminate the property of creditors pertama. 57

\section{- Objects in fiduciary sold to third parties}

Because objects collateral remains on the debtor, where people do not know that eigendom on it has been transferred to another party as a guarantee, to entrust a third party to purchase goods in fiduciakan it. The question is what if the object that has been in fiduciakan it is sold the debtor to a third party? Do kredittor can sue the object from the third party? In this case the creditor may demand the thing against anyone, if the fiduciary agreement between creditors to debtors that zakelijk created rights (the right material) for creditors. If the agreement fiduciary was merely obligatoir, but creditors can still sue them out of the power purchaser / third parties through Actio Pauliana, set out in article 1241 of the Civil Code, in which case they propose creditors is sufficient to prove that debt can be time doing something all know / realized that he was doing so detrimental to creditors, regardless of whether the people receiving benefits also know it or not.

\section{- The debtor does not fulfill the obligations}

In the case of credit secured loan agreement with iducia, how the act of the creditor if the debtor does not meet its obligations? Is it permissible to creditors have submitted objects as such guarantees? As in pawn / pand and mortgages, creditors should not have a fiduciary objects that are submitted as collateral and would be contrary to the provisions of Article 1178 and Article 1154 of the Civil Code. The existence of such a promise is void. This means that in the case of appointment Cidra debtor / defaulting then kreitor have to sell the collateral objects in public (auction) then take into account receivables.

Because Fiduciare Eigendom Overdracht (FEO) is not regulated in a special law, the parties are free to determine this agreement, among others, can also be mbahwa sale of the collateral can be done under the hands of the creditors, but sales under the hand will burden the creditor as well, especially regarding whether the sale price will satisfy the debtor or not. The lawsuit debtors to overcome, it is suggested that the minimum price specified in the agreement of the collateral goods if sold under the counter. Regarding the price should be the creditor is authorized to sell under the counter, with the provisions of ?? the price not lower than $10 \%$ below the appraisal value of $6 \%$ ?

\section{- Objects which Cannot be Encumbered with Fiduciary Security}

Fiduciary Security in Indonesia is defined by Law number 42/1999 on Fiduciary Security (Fiduciary Law) as the right covering moving objects both tangible and intangible and immovable objects which cannot be encumbered with a mortgage.

\footnotetext{
${ }^{9}$ A. Hamzah, Ibid, p. 64
} 


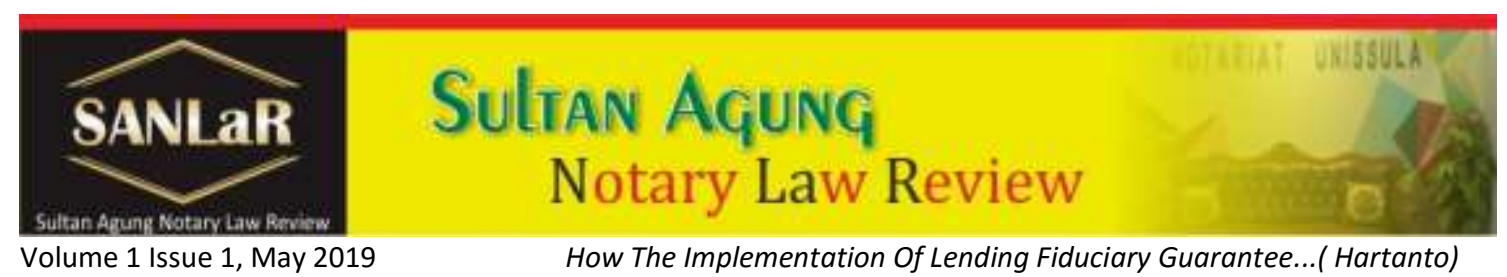

The objects will which remain in control of the person or entity which provides a fiduciary security over the objects (Fiduciary Provider). The Fiduciary Security is used to secure repayment of certain debt and gives the beneficiary of a Fiduciary Security (Fiduciary Beneficiary) a preferred position against other creditors.

Based on article 3 of the Fiduciary Law, the following objects cannot be secured by way of a Fiduciary Security: Encumbrance Rights (Hak Tanggungan) on land and landrelated objects which must be registered; Hypothecs on ships which are registered with the contents of gross measuring $20 \mathrm{M}^{3}$ or more and hypothecs on airplanes; and Pledges, where the debtor physically places the movable objects or intangible assets owned by the debtor into the possession of the creditor as security.

\section{- Imposition of Fiduciary Security on Objects}

Fiduciary Security cannot be imposed without any underlying agreement but is always a follow-up agreement of a principal agreement (for example a loan agreement in the event of a loan). The follow-up agreement creates an obligation of the Fiduciary Provider to fulfil a performance (for example repayment of loan). If such Fiduciary Provider does not fulfil such performance the Fiduciary Beneficiary has the right to sell the object, which is the object the Fiduciary Security, on his own power.

The imposition of Fiduciary Security on certain object must be conducted by way of notarial deed, the so called Fiduciary Deed. Such deed shall at least contain the following information: the identity of the Fiduciary Provider and the Fiduciary Beneficiary; data of the principal agreement; description of the object which will be secured; value of the security provided, and value of the secured object.

After the Fiduciary Deed is signed, the Fiduciary Beneficiary must register the object which is encumbered with the Fiduciary Security at the Fiduciary Registration Office. The registration shall at least contain the following information: the identity of the Fiduciary Provider and the Fiduciary Beneficiary; the date and number of the Fiduciary Deed, name and domicile of the notary which made the deed; data of the principal agreement; description of the object which will be secured; value of the security provided, and value of the secured object.

Based on the registration the Fiduciary Registration Office issues a Fiduciary Security Certificate to the Fiduciary Beneficiary. Such certificate has the same power as an executorial court decision, which means that the Fiduciary Beneficiary does not require a court decision in order to sell the object, in the event the Fiduciary Provider is in default.

\section{Closing}

\subsection{Conclution}


- In practice, the registration fee Fiduciary Deed (AJF) Fiduciary Registration Office (KPF) is more expensive and there is a levy based on a percentage of the value of fiduciary guarantee. This is not in line with the provisions of the deed of fiduciary manufacturing costs as specified in the Government Regulation No. 86 of 2000 on procedures for the registration fee fiduciary and fiduciary assurance Creation Deed, especially article 11 ;

- In some Fiduciary Registration Office (KPF), there is an opinion that the object of collateral in the form of the building stands on land that is not encumbered encumbrance, is not considered a fiduciary security object with a reason it is the authority of the Land Office. In Act 42 of 1999 on Fiduciary guarantees in article 1, paragraph (2) has been determined that the fiduciary is the right collateral to the moving objects both tangible and intangible and non-moving objects, especially buildings that can not be encumbered encumbrance referred in Act No. 4 of 1996 on the rights of dependents. Therefore, the sound of the sentence of Article 1 paragraph 2 may give rise to various interpretations and explanation of the sentence is also inadequate. In connection with this, then it should be made a more adequate explanation of the limits of the sentence referred to the competent authorities;

- It is necessary to regulate provisions that provide protection for creditors receiver fiduciary of a lawsuit / claim for ownership of the goods collateral in the form of inventory items to be transferred giver fiduciary, ie if it arises klaiam of third parties before the seller of goods inventory, which states that goods inventory which has been submitted to the fiduciary giver and receiver fiduciary collateral to creditors terbut payment has not been paid, so that the third party filed a lawsuit and the seizure of objects fiduciary concerned (it clashed with the confiscation revindikasi);

\subsection{Suggestions}

- Provisions concerning fees and fiduciary obligation to register needs to be improved, especially for the deed fidusianya binding object whose value change (is not fixed, like a sock / inventory should be changed every month); value (small credit limit while the large registration fee), and others.

- Fiduciary Registration Office until now have only been at the provincial level, the future need to be propagated to the district level.

- It needs to make provisions Fiduciary Issues Relating to Object That Abroad. According to Article 11, paragraph 2 UUJF contents are loaded fiduciary object is outside the territory of Indonesia, still must be registered. This article does not regulate where the place of incorporation in Jakarta or elsewhere. Besides, there is no regulation about execution.

\section{Reference}

[1] Book of the Law of Civil Law (Civil Code)

[2] Law No. 5 of 1960 About the Basic Regulation Agrarian

[3] Law No. 56 PRP Year 1960 On Determination of Agricultural Land. 


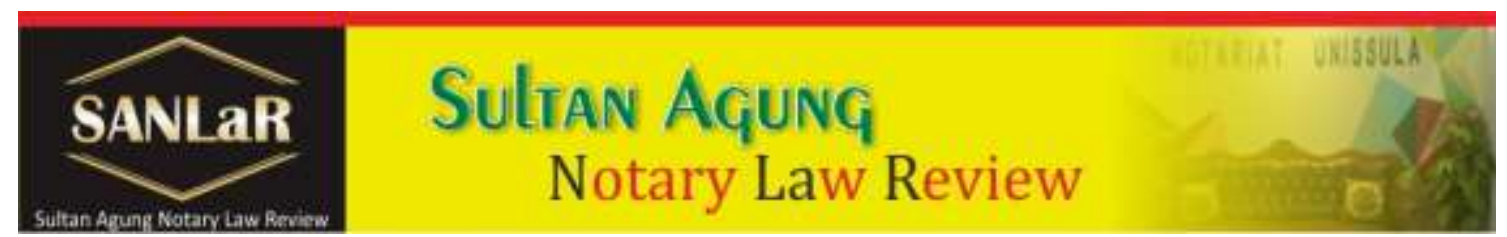

[4] Act No. 4 of 1996 on Mortgage Up Objects That Being on it

[5] Law No. 42 of 1999 concerning Guarantee Fiducia

[6] Government Regulation No. 86 Year 2000 Warranty Registration Procedures and Cost Fiducia Fiducia Manufacture Warranty Deed

[7] Government Regulation No. 10 of 1961 which has been replaced by Government Regulation No. 24 of 1997 Land Registration neighbor

[8] Government Regulation No. 40 of 1996 on the Right to Build, leasehold and Right to Use

[9] Government Regulation No. 41 of 1996 on the Rights Belongs To Strangers

[10] Presidential Regulation No. 44 of 2005 on the Ratification of the International Convention on Ship Mortgage.

[11] Satrio, J. 1993. Legal Rights Guarantees Guarantees material. Publisher PT Citra Aditya Bakti, Bandung.

[12] ------- 2003. Collateral material Jamiman Rights Law Fiducia, Publisher PT Citra Aditya Bakti, Bandung.

[13] Prodjodikoro, Wirjono.1981. About Civil Rights Objects. Publisher PT. Intermasa, Jakarta.

[14] Muhammad, Abdulkadir. 2004. Law and Legal Research. Publisher PT Citra Aditya Bakti, Bandung.

[15] Soedewi, Sri. 1981. Law Civil Benda. Publisher Liberty, Yogyakarta. 